\title{
Maternal Beslenme ve İlerleyen Yaşamda Obezite
}

\author{
Maternal Nutrition and Later Life Obesity \\ Fatma TAYHAN KARTAL ${ }^{1}$, Gizem HELVACI ${ }^{2}$, Nurcan YABANCI AYHAN ${ }^{3}$
}

\begin{abstract}
ÖZ
Beslenme fetal genomun ekspresyonunu değiş̧iren ve yaşam boyu sonuçları olabilecek ana intrauterin çevresel faktördür. Maternal dönemde, çok düşük veya yüksek enerji alımı, daha yüksek protein ve yağ alımı yenidoğanlarda obezite riskini arttırabilir. Bu durum cinsiyete göre değişmekle birlikte kızlar erkeklere göre daha savunmasızdır. Genel olarak gebelik sırasında yeterli ve dengeli protein ve enerji alımı yetişkin obezitesi için koruyucu bir faktör olabilir.
\end{abstract}

Gebeliğin erken dönemlerinden itibaren yeterli demir, krom, folik asit, vitamin $\mathrm{B}_{12}$ takviyeleri yenidoğanlarda obeziteyi önleyebilirken, aşırı folik asit, vitamin $B_{12}$ gibi metil vitaminleri ile aşırı multivitamin alımı da obezite riskini arttrabilir. Annedeki mevcut obezite veya gebelik sirasındaki özellikle de ilk trimesterdeki aşırı vücut ağırlığı kazanımı da birçok komplikasyonun yanında yenidoğanlarda obez olma riskini de arttırır.

Doğum ağırlığı ile BKİ, bel çevresi ve vücut yağ yüzdesi arasında U-şeklinde bir ilişsi vardır. Yapılan çalışmalarda hem yüksek doğum ağırlığının hem de düşük doğum ağırlı̆̆ının sonraki yaşamda obezite riski ile ilişkili olduğu gösterilmiştir. Optimal maternal beslenme doğum ağırlığını ve annenin gebelik sırasındaki vücut ağırlığı kazanımını etkileyerek obezite riskini azaltabilir. Optimal beslenmeyi teşvik etmek sadece optimal fetal gelişimi sağlamakla kalmaz, aynı zamanda ilerleyen dönemde obezite gelişme riskini de azaltır.

$\mathrm{Bu}$ derleme makalenin amacı, gebelikte maternal beslenme ve maternal vücut ağırlığı kazanımı, annenin vücut ağırlığı ve bebek doğum ağırlığı ile çocukluk, erişkinlik gibi ilerleyen dönemde obezite gelişimi ile olan ilişkilerini yapılan çalışmalar eşliğinde özetlemektir.

Anahtar Kelimeler: Gebelik, Maternal Beslenme, Obezite

\begin{abstract}
Nutrition is the primary intrauterine environmental factor, altering fetal genome expression that may have lifelong consequences. During the maternal period, very low or high energy intake, higher protein and fat intake may increase obesity risk in offspring. Although this varies by gender, female infants are more vulnerable than males. Generally, adequate and balanced protein and energy intake during the pregnancy can be protective against obesity in
\end{abstract} adulthood.

While adequate iron, chromium, folic acid, vitamin $\mathrm{B}_{12}$ supplements taken during early pregnancy can prevent obesity in offspring, methyl vitamins such as excessive vitamin $\mathrm{B}_{12}$, folic acid and multivitamin intake can also increase the risk of obesity. Present maternal obesity or excessive body weight gain during pregnancy, especially in the first trimester, increases the risk of obesity and complications in offspring.

There is a U-shaped correlation between birth weight and BMI, waist circumference and body fat percentage. Studies have shown that both high and low birth weights are associated with an increased obesity risk later in life. Optimal maternal nutrition can reduce obesity risk by affecting birth weight and mother's body weight gain during pregnancy. Encouraging optimal nutrition not only ensures optimal fetal development, but also reduces the obesity risk later in life.

This review article aims to summarize the relationship between maternal nutrition and maternal body weight gain in pregnancy, mother's body weight and baby's birth weight and the development of obesity in later periods of life, such as childhood and adulthood.

Keywords: Pregnancy, Maternal Nutrition, Obesity

\footnotetext{
${ }^{1}$ Arş. Gör. Gümüşhane Üniversitesi, Sağlık Bilimleri Fakültesi, Beslenme ve Diyetetik Bölümü, fatma_tayhan@hotmail.com, ORCID: 00000001-8524-9048

${ }^{2}$ Arş. Gör. Ankara Üniversitesi, Sağlık Bilimleri Fakültesi, Beslenme ve Diyetetik Bölümü, gizemhelvaci_165@hotmail.com, ORCID:0000-00018654-9245

${ }^{3}$ Prof. Dr. Ankara Üniversitesi, Sağlık Bilimleri Fakültesi, Beslenme ve Diyetetik Bölümü, nyabanci@ankara.edu.tr, ORCID:0000-0003-1233$246 \mathrm{X}$

\begin{tabular}{lll} 
İletişim / Corresponding Author: & Fatma TAYHAN KARTAL & Geliş Tarihi / Received: \\
e-posta/e-mail: & fatma_tayhan@hotmail.com & 11.11.2019 \\
Kabul Tarihi/Accepted: & 04.02 .2020 \\
\hline
\end{tabular}
}




\section{GíRIŞ}

Dünya genelinde 1,9 milyar yetişkin fazla kilolu (\%39) ve 650 milyon yetişkin (\%13) obezdir. Bu durum çocuklar için de geçerlidir. Beş yaş altındaki yaklaşık 41 milyon çocuk ve 5-19 yaş arası 340 milyon çocuk ve adölesan aşırı kilolu veya obezdir. ${ }^{1}$ Ülkemizin ilk olarak 2013 yılında dahil olduğu Çocukluk Çağı Şişmanlık Araştırması (COSI TUR) sonuçlarına göre ilkokul ikinci sınıf çocuklarda fazla kiloluluk ve obezite prevalans1 \%14,2 ve $\% 8,3$ olarak saptanmışken, 2016 yılında yapılan 4. turda fazla kiloluk ve obezite sirasiyla \%14,6 ve \%9,9 olarak bulunmuştur. ${ }^{2,3}$ Obezite küresel mortalite ve hastalık yükü için önde gelen risk faktörlerinden biri olarak kabul edilir. Enerji içeriği yüksek diyetler, hareketsiz yaşam tarzı ve genetik faktörler yetişkin obezitesinin ana nedenleri olsa da, fetal beslenme obezite salgınında önemli bir rol oynamaktadır. ${ }^{4,5}$

Annenin gebelik dönemindeki besin alımı, gelişmekte olan fetüs için tek besin ve besin kaynağ1 olup, doğum öncesi büyüme ve gelişmenin kritik bir belirleyicisidir. Gebelik döneminde yeterli miktarda ve sağlıklı beslenmenin önemi; bu dönemdeki mikronütrient veya toplam enerji alımındaki eksiklikler sonucunda yenidoğanda yetersiz büyüme ve uzun süreli sağlık sonuçları arasındaki ilişkinin varlığıyla gösterilmiştir. ${ }^{6}$ Maternal beslenme yetersizliği dünyanın birçok yerinde hala yaygın olsa da, sanayileşmiş ve yarı sanayileşmiş ülkelerin çoğunda, şu anda daha önemli bir sağlik sorunu aşırı enerji alımıdır. Maternal diyet bileşenleri (örneğin doymuş yağlar) veya besin grupları (işlenmiş gıdalar gibi) ve bunların aşırı alımı ilerleyen dönemde yenidoğanlarda obezite gelişimi için önemli bir risk faktörü olabilir. ${ }^{5} \mathrm{Bu}$ ilişki insanlarda olduğu gibi deneysel hayvan çalışmalarında da tutarlı bir şekilde gösterilmiştir., ${ }^{7,8}$

Maternal obezite ve gebelik sırasında aşırı vücut ağırlığı kazanımı da, fetüsün aşırı beslenmesine yol açarak, yenidoğanların yaşam boyu obeziteye yatkın olmasına neden olabilir. ${ }^{9}$ Ayrıca gebelikte aşırı vücut ağırlığı kazanımı bebeklerde doğum ağırlığının da bir belirleyicisi olup, ilerleyen dönemde obezite riskine neden olan makrozomik bebek ile sonuçlanabilir. ${ }^{10,11}$

Obezite genellikle vücut ağırlığının boy uzunluğunun karesine bölünmesiyle hesaplanan Beden Kütle İndeksi (BKI) ile tanımlanır. Pediatrik yaş grubunda ise fazla kiloluluk ve obezite cinsiyete özgü BKİ persentil değerleri ile tanımlanır. BKI'nin 85 . persentilin üzerinde ve 95. persentilin altında olmas1 fazla kiloluluk, 95. persentilden yüksek BKI'ye sahip çocuk ve adölesanlar ise obez olarak kabul edilir. ${ }^{4}$

$\mathrm{Bu}$ derlemenin amac1, gebelik dönemindeki beslenme, vücut ağırlığ1 kazanımı ve gebelik öncesi dönemdeki anne obezitesi ve yenidoğan doğum ağırlığı ile yenidoğanların çocukluk, adölesan ve yetişkinlik dönemlerinden an az birinde obeziteye yakalanma riski arasındaki ilişkiyi mevcut olan ilgili çalışmalarla özetlemektir. Ocak 2019-Nisan 2019 tarihleri arasında Science Direct, PubMed, Google Akademik veri tabanları kullanılarak araştırma yapılmıştır. Gebelik döneminde maternal diyet örüntüleri, maternal obezite ve gebelik sırasındaki vücut ağırlığı kazanımı ile doğum ağırlığı, fetal dönemde yağlanma ve çocuk obezitesi riski üzerindeki uzun dönem etkileri, annenin gebelik dönemindeki diyetiyle çocuğun diyeti arasındaki ilişkiyi inceleyen çalışmaları araştırmak için maternal diyet, diyet örüntüsü, obezite ve doğum ağırlığı gibi anahtar kelimeler kullanılmıştır. Gözlemsel ve deneysel insan ve hayvan çalışmaları, diyet müdahalesi içeren çalışmalar dâhil edilmiştir. Başlıklar ve özetler okunarak, potansiyel olarak alakalı olduğu düşünülen çalışmaların tam metinleri okunarak değerlendirmeye alınmıştır.

\section{Prenatal Dönemde Beslenme ve Obezite}

Genler her ne kadar obez olmaya eğilimi arttırsa da obez fenotipin ortaya çıkması için çevresel maruziyet gereklidir. Çevresel etkiler erken yaşta başlar. Organizmanın maruz kaldığ 1 ilk ortam anne karnıdır. İntra-uterin yaşamda organizma, özellikle embriyo ve fetüsün plasenta tarafindan anneden sağlanan besin öğesi ve oksijen kaynağına olan 
bağımlılı̆̆ı, metabolik düzenleme yollarının yanı sıra doku ve organların anatomik ve fonksiyonel olgunlaşmasının hızlı olması, çevresel değişikliklere tepki olarak dokulardaki farklılaşma nedeniyle çevreye duyarlıdır. ${ }^{12}$ Bu nedenle annenin tükettiği bazı besinler ve bu besinlerden sağlanan enerji ve besin öğeleri çocukların gerek iştah metabolizmasını etkileyerek, gerek metabolik bozukluklara yol açarak obez olma riskini etkileyebilir. Prenatal dönemde makro ve mikronütrientlerin etkisi aşă̆ıda verilmiştir:

\section{Prenatal Dönemde Makronütrientlerin Etkisi}

Maternal diyetin makrobesin öğesi içeriği, fetüsün rahimdeki metabolik programlanmasında rol oynar. Kordon kanı metabolik analizi, erken çocukluk çağı vücut ağırlı̆̆ı kazanımının besin bileşenlerine bağ $\left.\right|_{1}$ metabolitlerin regülasyonuyla ilişkili olduğunu göstermiştir. ${ }^{13}$ Kanttlar gebelikte yüksek yağlı bir diyet tüketiminin yenidoğanlarda obezite, metabolik sendrom gibi uzun vadeli bozuklukları tetikleyebileceğini göstermektedir. ${ }^{14}$ Chang ve arkadaşları, gebelik sırasında yüksek yağ $l_{1}$ bir diyet tüketiminin yenidoğanlarda paraventriküler nükleusta oreksijenik peptitlerde artışa neden olabileceğini göstermişlerdir. ${ }^{7}$

Elde edilen bulgular gebelikte yüksek yağ 1 ve abur-cubur diyetiyle beslenmenin yenidoğanlarda hiperinsülinemi ve hiperleptinemiye, mezolimbik ödül yolunun gelişimini değiştirerek besin tercihlerinde değişikliklere, hiperfajiye ve dolayısıyla obeziteye yol açabileceğini göstermiştir. ${ }^{8}$ Leptin, hipotalamus ve diğer beyin bölümleri (beyin sap1, amigdala) anoreksijenik ve oreksijenik nöropeptitlerin aktivitesini değiştirerek besin alımını azaltır. ${ }^{15}$ Maternal yüksek yağlı diyete maruz kalan yenidoğanların periferal dolaşımdaki leptin konsantrasyonlarının yükselmesinin yanı sıra hipotalamusta besin alımını, nöropeptit $\mathrm{Y}$ ve proopiomelanokortin gibi enerji dengesini kontrol eden nöropeptitlerin salınımını düzenleyen, fosforile STAT3 aktivasyonu azalmıştır. Bu durum da maternal yüksek yağlı diyetin hipotalamustaki leptin duyarlılığını azalttığını düşündürmektedir. ${ }^{16}$ Bu nedenle, merkezi leptin duyarsızlığı intrauterin dönemde maternal obezojenik diyetlere maruz kalan yenidoğanlarda artmış vücut ağırlığ1 kazanımı ve hiperfajinin temeli olabilir. ${ }^{17}$

Gebelik sırasında maternal protein alımı da çocuğun vücut kompozisyonu ile ilişkilendirilmiş̧ir. Gebelik sırasında protein alımı özellikle hayvansal kaynaklı proteinler fazla kilolu ve obez olma riskini arttırabilir. Ayrıca bu ilişki kadın cinsiyetinde daha güçlü bulunmuştur. ${ }^{18}$

Gebelik sirasinda yetersiz beslenmenin, yenidoğanları ilerleyen yıllarda obezite gibi metabolik patolojilere karşı duyarlı hale getirdiği bildirilmiştir. ${ }^{19}$ Yapılan eski çalışmalar, Hollanda Açlık kışı kitlığına (1944-1955) gebeliğinin ilk yarısında maruz kalan annelerden doğan bebeklerin 19 yaşında obez olma riski, açlğga maruz kalmayan annelerden doğan bebeklerle karşılaștırıldı ğında önemli derecede daha yüksek bulunmuştur. ${ }^{20}$ Ayrıca, prenatal dönemde protein ve enerji kısitlı diyetle beslenen farelerden doğan yavruların tercihlerinin yüksek yağlı yiyecekler yönünde olduğu gösterilmiştir. ${ }^{21}$ Buna göre prenatal dönemde beslenme yenidoğanların diyet tercihlerini etkileyebilir ve yenidoğanların ilerleyen yaşamlarında yağlanmaya katkıda bulunabilir.

Gebelik sırasında kümes hayvanları, kabuklu yemişler ve tam tahıl alımıyla karakterize bir diyetin, gebelikteki vücut ağırlığı kazanımıyla ilişkili olmasına rağmen, maternal açlık glikozu ve yenidoğan adipozitesi ile ilişkili olmadığı bulunmuştur. Nişastalı sebzeler, yumurta, katı yağlar ve işlenmiş tahıl tüketimi yüksek, yeşil yapraklı sebze, tam tahıl, süt ve süt ürünleri tüketimi düşük olan bir beslenme tarzı ise daha yüksek maternal açlık glikozu ve yenidoğan adipozitesiyle ve daha fazla doğum ağırlığıyla ilişkili bulunmuştur. ${ }^{22}$ Doğum ağırllı̆ı ve sonraki yaşamda obezite arasındaki ilişki aşağıda ayrıntılı olarak tartışılmıştır.

Annenin gebelikteki protein, yağ (enerji alımı için ayarlama yapıldıktan sonra) ve karbonhidrat alımı, çocukların diyetlerinde 
aynı besin öğelerindeki alımla pozitif olarak ilişkili bulunmuştur ve bu ilişki baba diyetiyle ilgili olarak gözlenenden daha kuvvetlidir. Potansiyel enerji yetersizliği için ayarlama yapıldıktan sonra çocuklarda daha fazla enerji ve makronütrient alımı daha fazla yağlanmayla ilişkili bulunmuştur. Gebelik sırasında annenin özellikle protein ve yağ alımı ile çocuğun diyetindeki bu besin öğelerini alımı arasındaki ilişki, doğum sonras1 dönemde annenin besin alımı ve çocuğun besin alımı arasındaki ilişkiye göre de daha güçlü bulunmuştur. ${ }^{23}$

\section{Prenatal Dönemde Mikronütrientlerin Etkisi}

Maternal mikrobesin öğesi durumu gelişmekte olan fetüs için önemli olup, fetal gelişimi etkileyebilir. Gebelik döneminde vitamin ve minerallerden yetersiz bir beslenmenin yenidoğanlarda vücut yă̆ yüzdesinde, abdominal obezitede artışla ilişskili olduğu gösterilmiştir. ${ }^{24} \mathrm{Krom}(\mathrm{Cr})$ glikoz ve yağ metabolizmasının düzenlenmesinde rol oynayan önemli bir mineraldir. Padmavathi ve arkadaşlarının, maternal $\mathrm{Cr}$ kisitlamasinın adipoz doku gelișimi ve fonksiyonu üzerindeki uzun dönem etkilerini belirlemek amaciyla yaptıkları bir çalışmada; Maternal $\mathrm{Cr}$ kısıtlaması (\%65), hem erkek hem de dişi yavrularda vücut ağırlığını ve yağ yüzdesini özellikle merkezi obeziteyi artırmıştır. ${ }^{25}$ Dolaşımdaki trigliserid ve serbest yağ asidi seviyeleri ise sadece diși yavrularda artmıștır. Başka bir çalışmada, maternal çinko kısıtlaması, vücut yă̆ yüzdesini arttırmış, yağsız kitleyi azaltmış ve açlık plazma insülin seviyelerini hem dişi hem de erkek yavrularda arttırmıştır. $^{26}$

Folik asit tek başına veya diğer B grubu vitaminleriyle birlikte, gebelikte en çok önerilen vitamindir. Eksikliği bebekte doğum kusurlarına neden olur. ${ }^{27}$ Maternal $\mathrm{B}_{12}$ vitamini ve folat kisitlamasinın yenidoğanlarda karın içi yağlanmayı arttırdığı, lipit metabolizmasını değiştirdiği ve özellikle dişi yavrularda vücut ağırlığını $\operatorname{arttırd} \breve{g}_{1}$ bulunmuştur. ${ }^{28}$ Bunun aksine gebelik sırasında fazla tüketilen B vitaminleri homeostatik ve hedonik besin alımı düzenleyici yolların gelişimini ve aynı zamanda yenidoğanda yağ depolanmasını etkileyerek obeziteye neden olabilir. Farelerde yüksek metil-vitamin alımı hipotalamustaki DNA metilasyonuna yol açar ki bu da beslenmeyle ilişkili nöropeptitlerin gen ekspresyonundaki değişimlerle uyumludur, bu da yenidoğanlarda artan besin alımı, vücut ağırlığı kazanımı ve diğer metabolik bozuklukların gelişimini desteklemektedir. ${ }^{25}$ Gebeliğin 28. haftasında daha yüksek maternal folat konsantrasyonu yenidoğanlarda daha yüksek adipozite ve HOMA-R seviyeleriyle ilișkili bulunmuştur. Düşük maternal $\mathrm{B}_{12}$ vitamini seviyesi de çocuklarda daha yüksek HOMA-R ile ilişkili olup, yüksek folat ve düşük $B_{12}$ vitamini konsantrasyonlarının ikisine birden sahip olan annelerin çocukları insülin direnci yönünden daha fazla risk altındadır. ${ }^{29}$

Demir fetüs için hayati bir öneme sahip esansiyel bir mikrobesin öğesidir. Gebelikte demir eksikliği anemisi yüksek gelirli ülkelerde bile hala yaygın bir sorundur. Eğer gebeliğin başlangıcında yetersiz demir depoları varsa gebelik sirasındaki gereksinimler tam olarak karşılanamayabilir. ${ }^{30}$ Annedeki demir eksikliği varlığının yenidoğanlarda obezite, hipertansiyon ve kardiyovasküler hastalıkların gelişmesiyle sonuçlanacağı bildirilmiştir. ${ }^{31}$

Vitamin D insan vücudu için gerekli olan ve yağda çözünen bir vitamindir. Vitamin D eksikliği yenidoğanlarda obezite riskini etkileyen, gebe kadınlar arasında yaygın olan küresel bir sağlık sorunudur. ${ }^{32}$ Vitamin D yağ dokusu kütlesini, farklılaşmasını ve metabolizmasını, muhtemelen lipogenez ve adipogenez üzerindeki etkileriyle, fazla kiloluluk veya obeziteye katkıda bulunabilecek şekilde düzenleyebilir. ${ }^{31}$ Yapılan bir çalışmada, maternal D vitamini yetersizliği, yenidoğanda daha düşük yağ kitlesiyle ilişkili olmasına rağmen, 4 ve 6 yaşındaki ölçümlerde daha fazla yağ kitlesiyle ilişkili bulunmuştur. Yenidoğanda ve 6 yaşındaki çocukta yağ kitlesi ve annenin D vitamini durumu arasındaki ilișkinin, karıştırıcı faktörler (annenin BKI'si ve 
gebelikteki vücut ağırlığı kazanımı gibi) için düzeltme yapıldıktan sonra daha da güçlü olduğu görülmüştür. ${ }^{34}$ Maternal $\mathrm{D}$ vitamini eksikliğine maruz kalmanın yenidoğanda adipoz doku gelişiminde rol oynayan genleri etkileyebileceği bildirilmiştir. ${ }^{32}$

Gebeliğin erken dönemlerinden itibaren krom, demir ve D vitamini takviyeleri bu gebeliklerden doğan çocuklarda fazla kilolu ve obez olma riskini azaltabilir. Vitamin $B_{12}$ ve folik asit takviyesinin ise hem yüksek hem de düşük dozları yenidoğanlar için ileriki yaşlarda yağlanma ile pozitif yönde ilişkili olabilir.

\section{Maternal Obezite ve Doğum Ağırlığının Obeziteye Etkisi}

Annenin hem gebelik öncesi dönemdeki vücut ağırlığı hem de gebelik sırasındaki vücut ağırlığı kazanımı çocuklarının ilerleyen yaşamlarında obezite riskiyle karşı karşıya kalmalarına sebep olabilir. Annenin gebelik öncesi ve gebelik dönemindeki BKİ'si ile yenidoğan doğum ağırlığının obeziteye etkisi aşağıda sunulmuştur:

\section{Gebelik Öncesi Dönemde BKİ ve Yenidoğanlarda Obezite}

Gebelik öncesi dönemdeki obezite, çocuk için obezite açıısından bir risk faktörüdür. ${ }^{35}$ Obez annelerin çocukları adipogenezis ve lipogenezisin up-regülasyonunun bir sonucu olarak, adipozite, adipozit hipertrofisi ve erişkinlikte vücut ağıllık artışına yatkındır. ${ }^{36}$ Yapılan bir çalışmaya göre, gebelik öncesi dönemdeki BKİ'deki her bir birim artışın, doğum ağırlığını $17 \mathrm{~g}$ arttırdığı bulunmuştur. ${ }^{37}$ Hayvanlarda yapılan çalışmalar obez anne ve babaların gametlerinden doğan in-vitro olarak döllenmiş ve zayıf taşıyıcı hayvanlara nakledilmiş yavruların yetişkin dönemde obez olma ve insülin direnci geliştirme riskinin yüksek olduğunu göstermiştir. Dahası hem erkek hem de dişi gametlerin dişi yavrular üzerinde obezite geliştirme yönünden katkısı varken, erkek yavrular üzerinde obezite geliştirme yönünden katkısı bulunmamıştır. Erkek yavrular baba gametlerinden bağımsız olarak obez annelerin gametlerine sahipse obezite gelişme riski en yüksek olarak bulunmuştur. $\mathrm{Bu}$ nedenle obez annelerin çocukları intra-uterin yaşama bakılmaksızın obez babaların çocuklarına göre daha fazla obezite gelişme riskine sahiptir. ${ }^{35}$ İnsanlarda yapılan bir çalışmada ise maternal gastrointestinal bypass cerrahisi yapilan annelerde, ameliyattan önce aynı anneden doğan çocuklarla karşılaştırıldığında, ameliyattan sonra doğan çocuklarda obezite prevalansı azalmıştır. Böylece ameliyattan sonra doğan çocuklara obezitenin taşınması önlenebilir. ${ }^{38}$

Maternal obezite ile çocukların ilerleyen dönemde obez olma riski arasındaki ilişkiyi şu şekilde açıklayabiliriz: Adipoz doku, otokrin, parakrin ve endokrin etkileri olan leptin ve adiponektin gibi adipositokinleri üretir ve insülin duyarlılığını, dolayısıyla metabolik hastalıkların gelişimini etkiler. Adiponektin insülin duyarlılığını arttırı ve antiinflamatuar özelliklere sahiptir; azalmış dolaşım seviyeleri obezite, insülin direnci ve tip2 diyabetle ilişkilidir. Obez gebelerde adiponektin seviyeleri düşüktür, benzer şekilde yenidoğanlarının da adiponektin seviyeleri düşüktür. Leptin ise tokluk ve enerji dengesinin düzenlenmesinde önemli roller oynar. Obez annelerin yenidoğanlarında leptin düzeyi yükselmiş olmasına rağmen, maternal obezite leptin direncini uyardığı için yenidoğanların besin alımında azalma gözlenmez. Maternal obezite maternal lipit mobilizasyonu ve trigliseritlerde daha büyük artı̧̧la iliş̧kilidir. LDL-kolesterol ve serbest yağ asidi normal kilolu gebelere kiyasla obez gebelerde artmıştır. Maternal obezite serbest yağ asidi taşıyıcılarının plasenta içine ekspresyonunu arttrirr, bunlar da fetal dolaşımdaki lipitlerin artmasıyla, dolayısıyla yenidoğan obezitesiyle ilişkilidir. ${ }^{36}$

\section{Gebelik Döneminde Vücut Ağırlı̆̆ Kazanımı ve Yenidoğanlarda Obezite}

Gebelikteki obezite gestasyonel diyabet, intrauterin büyüme geriliği, makrozomik bebek, artmış sezaryen oranları ve düşükleri içeren birçok komplikasyonla ilişkilidir. Maternal obezitenin etkisi yenidoğan döneminin de ötesine geçerek, gelecek nesiller üzerinde uzun vadeli zararlı etkileri olabilir. Besin ortamındaki değişiklikler de 
dahil olmak üzere, anne karnındaki çevresel maruziyetler, hızlı büyümenin olduğu bu dönemde oldukça önemlidir. ${ }^{13}$

Gebelik boyunca tavsiye edilen vücut ağırlığı kazanımı BKI'ye göre değişmekle birlikte, düşük kilolu gebeler için 12,5-18kg, normal kilolu gebeler için 11,5-16 kg, hafif şişman ve obez gebeler için sırasıyla 7-11,5 kg ve 7 kg'dan az şeklindedir. ${ }^{39}$ Gebelik döneminde aşırı vücut ağırlığı kazanımı çocuklukta obezite gelişme riski ile ilişkilidir. ${ }^{10}$ Özellikle gebeliğin ilk trimesterinde fazladan vücut ağırlığı kazanımı (gebelik döneminde haftada $200 \mathrm{~g}$ fazladan vücut ağırlığ1 kazanımı, obezite riskini \%22 arttırır) obezite riskini önemli ölçüde arttırır. ${ }^{40}$ Switkowski ve arkadaşları, annenin BKI'sinin ve gebelik dönemindeki vücut ağırlığ kazanımının bebeğin doğum ağırlığıyla anlamlı olarak ilişkili olduğunu bulmuşlardır. ${ }^{41}$ Doğum ağırlığı da bebeğin ilerleyen dönemlerde obez olma riskiyle ilişkilidir. Toplum temelli prospektif bir çalışmada, yenidoğan ağırlığ normal kilolu annelerden doğanlarda, fazla kilolu, obez ve düşük kilolu annelerden doğanlara göre daha düşük bulunmuştur. Gebelik sirasında her bir kilogram artış doğum ağırlığında $20 \mathrm{~g}$ artışa yol açmıştır. ${ }^{37}$

\section{Doğum Ăğırlığı ve Obezite}

Çocukluk, yetişkinlik gibi ilerleyen dönemlerde obezitenin potansiyel belirleyicilerinden biri de yenidoğan doğum ağırlığıdır. Özellikle insanlarda hem düşük hem de yüksek doğum ağırlığ ve yetişkin dönemi obezitesi için bir risk faktörü olup, her iki durumun da obezite riskini arttırdığ 1 düşünülmektedir. ${ }^{11}$ ABD'de yaklaşık 14,000 adölesan üzerinde yapılan bir kohort çalışmasında, zamanında doğan bebeklerde doğum kilosunda 1 kg'lık artış, 914 yaşları arasında fazla kilolu olma riskinde yaklaşık \%50 artış ile ilişkili bulunmuştur. Maternal BKİ için ayarlama yapıldıktan sonra bile fazla kilolu olma riskindeki \%30 artış anlamlı bulunmuştur. ${ }^{10}$ Benzer şekilde düşük doğum ağırlığı da ilerleyen yaşamda obezitenin gelişmesine neden olabilir. ${ }^{20}$ İsviçre'de yaşayan 35-75 yaşları arasındaki 1458 kadın ve 1088 erkek üzerinde yapılan toplum temelli kesitsel bir çalışmada, düşük doğum ağırlıklı kadınların $(\leq 2,5)$ daha yüksek plazma açlık glikozu, insülin ve HOMA seviyelerine, daha yüksek oranda diyabet ve metabolik sendroma sahip olduğu görülmüştür. Doğum ağırlığı ile BKİ, bel çevresi ve vücut yağ yüzdesi arasında Uşeklinde bir ilişki bulunmuştur. ${ }^{42}$

\section{SONUÇ VE ÖNERILER}

Obezite dünya genelinde önemli ve artmaya devam eden bir sorundur ve bu sorunun önlenmesi gerekmektedir. Genel olarak gebelik sırasında yeterli ve dengeli protein ve enerji alımı yetişkin dönemdeki obezite için koruyucu bir faktör olabilir ve kızlar erkeklere göre daha fazla risk altında olabilir. Benzer şekilde gebelik sırasında çok düşük enerji ve protein alımı da yenidoğanların ilerleyen yaşamlarında aşırı kilolu olma riskini arttırabilir. Gebeliğin erken döneminden başlayarak demir, çinko ve folik asit takviyesi çocukluk çağı şişmanlığını önleyebilir. Gebelikteki vitamin $\mathrm{B}_{12}$ düzeyi de yaşamın ilerleyen dönemlerinde adipozite ile negatif yönde ilişkili olabilir.

Hem gebelik öncesi dönemde maternal obezite hem de gebelik dönemindeki aşırı vücut ağırlığı kazanımı birçok komplikasyonla ilgili olmakla birlikte bu gebeliklerden doğan çocukların ilerleyen dönemde fazla kilolu ve obez olma riskiyle de pozitif yönde ilişkilidir. Bu nedenle bir bebek sahibi olmak isteyen kadınlar gebe kalmadan önceden itibaren takip edilmeli ve ortaya çıkması muhtemel olan komplikasyonların oluşma riskini azaltmak için gerekli önlemler alınmalıdır.

Gebe kadınların beslenme durumlarının iyileştirilmesi, düşük doğum ağırlı̆̆ veya makrozomik bebek riskini önemli ölçüde azaltabilir. Hem düşük doğum ağırlığı hem de gestasyonel yaşa göre yüksek doğum ağırlığına sahip bebekler hayatlarının daha sonraki dönemlerinde obezite için risk altındadırlar. 
Mevcut bulguları doğrulamak için maternal protein ve enerji alımı ya da mikronütrient takviyesinin yenidoğan obezitesi üzerindeki etkilerini değerlendiren randomize kontrollü çalışmalara ihtiyaç duyulmaktadır.

\section{KAYNAKLAR}

1. WHO (2018). Obesity and owerveight https://www.who.int/news-room/fact-sheets/detail/obesity-andoverweight (Erişim tarihi: 06/01/2020)

2. Türkiye çocukluk çağı (7-8 yaş) şişmanlık araştırması (COSITUR), 2013. T.C. Sağlık Bakanlığı, Türkiye Halk Sağlığ Kurumu, Milli Eğitim Bakanlığı, Hacettepe Üniversitesi. Ankara: Türkiye. https://hsgm.saglik.gov.tr/depo/birimler/saglikli-beslenmehareketli-hayat-db/Yayinlar/kitaplar/diger-kitaplar/cosi-tr.pdf (Erişim tarihi: 06/01/2020).

3. Türkiye Çocukluk Çağı (ilkokul 2. sınıf öğrencileri) Şişmanlık Araştırması (COSI-TUR), 2016. T.C. Sağlık Bakanlığı, Türkiye Halk Sağlığı Genel Müdürlüğü, Milli Eğitim Bakanlığı, Dünya Sağllk Örgütü Avrupa Bölge Ofisi. Ankara: Türkiye. https://hsgm.saglik.gov.tr/depo/haberler/turkiye-cocukluk-cagisismanlik/COSI-TUR-2016-Kitap.pdf (Erişim tarihi: 06/01/2020).

4. Güngör, N.K. (2014). 'Overweight and obesity in children and adolescents'. Journal of clinical research in pediatric endocrinology, 6 (3), 129-143.

5. Muhlhausler, B.S. ve Ong Z.Y. (2011). 'The fetal origins of obesity: early origins of altered food intake'. Endocr Metab Immune Disord Drug Targets, 11 (3), 189-97.

6. Hu, X.F., G.G. Liu, ve Fan, M. (2017). 'Long-Term Effects of Famine on Chronic Diseases: Evidence from China's Great Leap Forward Famine'. Health Economics, 26 (7), 922-936.

7. Chang, G., Gaysinskaya, V., Karatayev, O., Leibowitz S.F. (2008). 'Maternal high-fat diet and fetal programming: increased proliferation of hypothalamic peptide-producing neurons that increase risk for overeating and obesity'. Journal of Neuroscience, 28 (46), 12107-12119.

8. Ong, Z.Y. ve Muhlhausler, B. (2011). 'Maternal "junk-food" feeding of rat dams alters food choices and development of the mesolimbic reward pathway in the offspring'. The FASEB Journal, 25 (7), 2167-2179.

9. Groth, S.W., Holland, M.L., Smith J.A., Mng, Y., Kitzman, H. (2017). 'Effect of Gestational Weight Gain and Prepregnancy Body Mass Index in Adolescent Mothers on Weight and Body Mass Index of Adolescent Offspring'. The Journal of adolescent health: official publication of the Society for Adolescent Medicine, 61 (5), 626-633.

10. Gillman, M.W., Rifas-Shiman, S., Berkey, C.S., Field, A.E., Colditz, G.A. (2003). 'Maternal gestational diabetes, birth weight, and adolescent obesity'. Pediatrics, 111 (3), e221-e226.

11. Gluckman, P.D., Hanson, M.A., Morton, S.M., Pinal, C.S. 'Lifelong echoes--a critical analysis of the developmental origins of adult disease model. Biol Neonate, 2005. 87 (2), 127-139.

12. Maffeis, C. ve Morandi, A. (2017). 'Effect of Maternal Obesity on Foetal Growth and Metabolic Health of the Offspring'. Obesity facts, 10 (2), 112-117.

13. Elshenawy, S. ve Simmons, R. (2016). 'Maternal obesity and prenatal programming'. Molecular and Cellular Endocrinology, $435,2-6$.

14. Lemes, S.F., de Souza, A.C.P., Payolla, T.B., Versutti, M.D., de Fatima da Silva Ramalho, A., Mendes-da-Silva, C. ve ark. (2018). 'Maternal Consumption of High-fat Diet in Mice Alters Hypothalamic Notch Pathway, NPY Cell Population and Food Intake in Offspring'. Neuroscience, 371, 1-15.
15. Yeo, G.S. ve Heisler, L.K. (2012). 'Unraveling the brain regulation of appetite: lessons from genetics'. Nat Neurosci, 15 (10), 1343-1349.

16. Sun, B., Prcell, R.H., Terrilllion, C.E., Yan, J., Moran, T.H., Tamashiro, K.L. (2012. 'Maternal high-fat diet during gestation or suckling differentially affects offspring leptin sensitivity and obesity'. Diabetes, 61 (11), 2833-2841.

17. Grayson, B.E., Levasseur, P.R., Williams, S.M., Smirth, M.S., Marks, D.L., Grove, K.L. (2010). 'Changes in melanocortin expression and inflammatory pathways in fetal offspring of nonhuman primates fed a high-fat diet'. Endocrinology, 151 (4), $1622-1632$.

18. Maslova, E., Rytter, D., Bech, B.H., Henriksen, T.B., Rasmussen, M.A., Olsen, S.F. ve ark. (2014). 'Maternal protein intake during pregnancy and offspring overweight 20 y later'. Am J Clin Nutr, 100 (4), 1139-1148.

19. Lecoutre, S., Marousez, L., Drougard, A., Knauf, C., Guinez, C., Elberle, D. ve ark. (2017). 'Maternal undernutrition programs the apelinergic system of adipose tissue in adult male rat offspring'. Journal of Developmental Origins of Health and Disease, 8 (1), 3-7.

20. Ravelli, G.P., Stein, Z.A. ve Susser, M.W. (1976). 'Obesity in young men after famine exposure in utero and early infancy'. N Engl J Med, 295 (7), 349-353.

21. Taylor, P.D. ve Poston, L. (2007). 'Developmental programming of obesity in mammals'. Exp Physiol, 92 (2), 287-298.

22. Starling, A.P., Sauder, K.A., Kaar, J.L., Shapiro, A.L., SiegaRiz, A.L., Dabelea, D. (2017). 'Maternal Dietary Patterns during Pregnancy Are Associated with Newborn Body Composition'. The Journal of nutrition, 147 (7), 1334-1339.

23. Brion, M.J.A., Ness A.R., Rogers, I., Emmet, P., Cribb, V., Smith G.D. ve ark. (2010). 'Maternal macronutrient and energy intakes in pregnancy and offspring intake at $10 \mathrm{y}$ : exploring parental comparisons and prenatal effects'. The American journal of clinical nutrition, 91 (3), 748-756.

24. Lagishetty, V., Nandiwada, V.B., Kalashikam, R.R., Manchala, R. (2007). 'Effect of maternal vitamin and mineral restrictions on the body fat content and adipocytokine levels of WNIN rat offspring'. Nutrition \& metabolism, 4, 21-25.

25. Padmavathi, I.J., Rao, K.R., Venu, L., Ganeshan, M., Kumar, K.A., Rao, C.N. ve ark. (2010). 'Chronic maternal dietary chromium restriction modulates visceral adiposity: probable underlying mechanisms'. Diabetes, 59 (1), 98-104.

26. Padmavathi, I.J., Kishore, Y.D., Venu, L., Ganeshan, M., Harishankar, N., Giridharan, N.V. ve ark. (2009). 'Prenatal and perinatal zinc restriction: effects on body composition, glucose tolerance and insulin response in rat offspring'. Exp Physiol, 94 (6), 761-769.

27. Pannia, E., Clara, E.C., Kubant, R., Sanchez-Hernandez, D., Huot, P.S.P., Anderson, G.H. (2016). 'Role of maternal vitamins in programming health and chronic disease'. Nutrition reviews, $74(3), 166-180$.

28. Kumar, K.A., Lalitha, A., Pavithra, D., Padmavathi, I.J., Ganeshan, M., Rao, K.R. ve ark. (2013). 'Maternal dietary folate and/or vitamin B12 restrictions alter body composition (adiposity) and lipid metabolism in Wistar rat offspring'. J Nutr Biochem, 24 (1), 25-31. 
29. Yajnik, C.S., Deshpande, S.S., Jackson, A.A., Refsum, H., Rao, S., Fisher, D.J. ve ark. (2008). 'Vitamin B12 and folate concentrations during pregnancy and insulin resistance in the offspring: the Pune Maternal Nutrition Study'. Diabetologia, 51 (1), 29-38.

30. Alwan, N.A. ve Hamamy, H. (2015). 'Maternal Iron Status in Pregnancy and Long-Term Health Outcomes in the Offspring'. J Pediatr Genet, 4(2), 111-123.

31. Zhang, J., Lewis, R.M., Wang, C., Hales, N., Byrne, C.D. (2005) 'Maternal dietary iron restriction modulates hepatic lipid metabolism in the fetuses'. Am J Physiol Regul Integr Comp Physiol, 288(1), R104-111.

32. Belenchia, A.M., Johnson, S.A., Ellersieck, M.R., Rosenfeld C.S., Peterson, C.A. (2017). 'In utero vitamin D deficiency predisposes offspring to long-term adverse adipose tissue effects'. J Endocrinol, 234(3), 301-313.

33. Cerit, Z. (2017). 'Maternal depression, vitamin D, and offspring obesity'. The Journal of Pediatrics, 182, 407-408.

34. The SWS Study Group. (2012). 'Maternal vitamin D status in pregnancy is associated with adiposity in the offspring: findings from the Southampton Women's Survey'. The American Journal of Clinical Nutrition, 96 (1), 57-63.

35. Huypens, P., Sass, S., Wu, M., Dyckhoff, D., Tschöp, M., Theis, F. ve ark. (2016). 'Epigenetic germline inheritance of dietinduced obesity and insulin resistance'. Nat Genet, 48 (5), 497 499.
36. Glastras, Sarah J., Chen, H., Pollock, C.A., Saad, S. (2018) 'Maternal obesity increases the risk of metabolic disease and impacts renal health in offspring'. Bioscience Reports, 38 (2), BSR20180050.

37. Diemert, A., Lezius, S., Pagenkemper, M., Hansen, G., Drozdowska, A. Hecker, K. ve ark. (2016). 'Maternal nutrition, inadequate gestational weight gain and birth weight: results from a prospective birth cohort'. BMC Pregnancy Childbirth, 16, 224.

38. Kral, J.G., Biron, S., Simard, S., Hould, F.S., Lebel, S., Marceau, S. ve ark. (2006). 'Large maternal weight loss from obesity surgery prevents transmission of obesity to children who were followed for 2 to 18 years'. Pediatrics, 118 (6), e1644-9.

39. Daşıkan, Z. and Kavlak, O. (2009). 'Maternal Obezite: Gebelik komplikasyonları ve gebe kadının yönetimi'. Turkiye Klinikleri Journal of Nursing Sciences, 1 (1), 39-46.

40. Karachaliou, M., Georgiou, V., Roumeliotaki, T., Chaldiaki, G., Daraki, V., Koinaki, S. ve ark. (2015). 'Association of trimesterspecific gestational weight gain with fetal growth, offspring obesity, and cardiometabolic traits in early childhood'. Am J Obstet Gynecol, 2015. 212 (4), 502.e1-502.14.

41. Switkowski, K.M., Jacques, P.F., Must, A., Kleinmen, K.P., Gillman, M.W., Oken, E. (2016). 'Maternal protein intake during pregnancy and linear growth in the offspring'. Am J Clin Nutr, 104 (4), 1128-1136.

42. Jornayvaz, F.R., Vollenweider, P., Bochud, M., Mooser, V. Waeber, G., Marques-Vidal, P. (2016). 'Low birth weight leads to obesity, diabetes and increased leptin levels in adults: the CoLaus study'. Cardiovascular Diabetology, 15 (1), 73. 